\title{
Temperature induced decoupling of enzymatic hydrolysis and carbon remineralization in long-term incubations of Arctic and temperate sediments
}

\author{
Alberto Robador ${ }^{\mathrm{a}, *}$, Volker Brüchert $^{\mathrm{b}}$, Andrew D. Steen ${ }^{\mathrm{c}, 1}$, Carol Arnosti ${ }^{\mathrm{c}}$ \\ ${ }^{a}$ Department of Biogeochemistry, Max Planck Institute for Marine Microbiology, Celsiusstr. 1, 28359 Bremen, Germany \\ ${ }^{\mathrm{b}}$ Department of Geology and Geochemistry, Stockholm University, 10691 Stockholm, Sweden \\ ${ }^{\mathrm{c}}$ Department of Marine Sciences, University of North Carolina, Chapel Hill, NC 27599-3300, USA
}

Received 8 May 2009; accepted in revised form 1 December 2009; available online 28 January 2010

\begin{abstract}
Extracellular enzymatic hydrolysis of high-molecular weight organic matter is the initial step in sedimentary organic carbon degradation and is often regarded as the rate-limiting step. Temperature effects on enzyme activities may therefore exert an indirect control on carbon mineralization. We explored the temperature sensitivity of enzymatic hydrolysis and its connection to subsequent steps in anoxic organic carbon degradation in long-term incubations of sediments from the Arctic and the North Sea. These sediments were incubated under anaerobic conditions for 24 months at temperatures of 0,10 , and $20{ }^{\circ} \mathrm{C}$. The short-term temperature response of the active microbial community was tested in temperature gradient block incubations. The temperature optimum of extracellular enzymatic hydrolysis, as measured with a polysaccharide (chondroitin sulfate), differed between Arctic and temperate habitats by about $8-13{ }^{\circ} \mathrm{C}$ in fresh sediments and in sediments incubated for 24 months. In both Arctic and temperate sediments, the temperature response of chondroitin sulfate hydrolysis was initially similar to that of sulfate reduction. After 24 months, however, hydrolysis outpaced sulfate reduction rates, as demonstrated by increased concentrations of dissolved organic carbon (DOC) and total dissolved carbohydrates. This effect was stronger at higher incubation temperatures, particularly in the Arctic sediments. In all experiments, concentrations of volatile fatty acids (VFA) were low, indicating tight coupling between VFA production and consumption. Together, these data indicate that long-term incubation at elevated temperatures led to increased decoupling of hydrolytic DOC production relative to fermentation. Temperature increases in marine sedimentary environments may thus significantly affect the downstream carbon mineralization and lead to the increased formation of refractory DOC.
\end{abstract}

(c) 2010 Elsevier Ltd. All rights reserved.

\section{INTRODUCTION}

Recent research on global climate change has shown that some of the most pronounced increases in temperature are expected to occur in the Arctic regions (Anisimov et al.,

\footnotetext{
${ }^{*}$ Corresponding author. Present address: Department of Oceanography, University of Hawaii, NASA Astrobiology Institute, Honolulu, HI 96822, USA. Tel.: +1 8089568800.

E-mail address: arobador@hawaii.edu (A. Robador).

${ }^{1}$ Present address: Center for Geomicrobiology, University of Århus, Ny Munkegade, Bld. 1535, 8000 Århus C, Denmark.
}

2007). Over the period 1920-1998, seasonal temperatures in the Arctic archipelago of Svalbard have gradually increased (winter $+1{ }^{\circ} \mathrm{C}$, spring and summer $+0.5^{\circ} \mathrm{C}$, autumn $0.0^{\circ} \mathrm{C}$; Hanssen-Bauer, 2002). Warming by as much as $3-4{ }^{\circ} \mathrm{C}$ has been predicted for the Arctic surface temperatures over the next century (Moritz et al., 2002), with consequences for enhanced nutrient and carbon runoff, changes in sea ice coverage, air-sea $\mathrm{CO}_{2}$ exchange, and primary production in Arctic shelves (Loeng et al., 2005; Denman et al., 2007).

Almost $50 \%$ of the Arctic Ocean is in water depths less than $50 \mathrm{~m}$ (Jakobsson et al., 2003) so that a large fraction of organic matter exported from the euphotic zone reaches 
the seafloor. In shelf sediments, anaerobic pathways may comprise between $30 \%$ and $90 \%$ of the mineralization of organic matter to $\mathrm{CO}_{2}$ (Canfield et al., 1993). In sediments, benthic microbial communities enzymatically hydrolyze organic substrates to sizes sufficiently small (ca. $600 \mathrm{Da}$; Benz and Bauer, 1988) to permit uptake. The hydrolysis products are subsequently fermented, mainly to low-molecular weight organic compounds such as volatile fatty acids (VFA) (Capone and Kiene, 1988), and then oxidized to $\mathrm{CO}_{2}$. Since burial of organic carbon in the Arctic Ocean may account for ca. $7-11 \%$ of the global budget (Stein and Macdonald, 2004), understanding the temperature response of carbon production, recycling, and preservation in Arctic sediments is crucial for prediction of the effects of climate change on the global carbon cycle (Belicka et al., 2002).

Because benthic microbial communities in Arctic sediments include psychrophilic organisms that are welladapted to cold conditions (e.g., Knoblauch and Jørgensen, 1999), the response of Arctic sedimentary microbial communities to temperature changes can best be investigated by comparison with temperate sedimentary communities. Microbial communities that experience a considerable temperature range on an annual basis may respond differently to warming than Arctic communities. Furthermore, longterm changes in temperature may lead to shifts in microbial community composition, such that numerically minor members of a community that are more tolerant to higher temperatures may become dominant given sufficient time, and their carbon cycling capabilities could then dictate the response of the net community (e.g., Robador et al., 2009). In order to investigate such a possibility, long-term rather than short-term experimental temperature shifts are required.

Temperature response profiles of polysaccharide hydrolysis and sulfate reduction in freshly-collected permanently cold and seasonally changing sediments have shown that under in situ conditions, there is a close coupling between these two key phases of organic matter degradation (Arnosti et al., 1998). Comparative studies from temperate and Arctic sediments (Arnosti and Holmer, 2003; Brüchert and Arnosti, 2003; Arnosti and Jørgensen, 2006) of the initial and terminal steps of organic carbon degradation suggested that turnover of carbon through the dissolved pool occurs quite rapidly. Moreover, an experimental study of the effect of sudden temperature changes on the robustness of this coupling showed a strong balance over a temperature range that exceeds environmental conditions of both temperate and Arctic marine sediments (Finke and Jørgensen, 2008). An investigation of sulfate reduction in Arctic and temperate sediments carried out concurrently with this study, however, showed that long-term temperature increases may have a pronounced effect on rates of sulfate reduction as well as on the composition of the sulfatereducing community, and therefore on the extent to which organic matter is recycled or preserved in marine sediments (Robador et al, 2009).

In this study, the temperature sensitivity of enzymatic hydrolysis in Arctic and temperate marine sediments was investigated using a polysaccharide substrate, because carbohydrates are major components of both particulate and dissolved organic carbon in sediments (Arnosti and Holmer, 1999). The polysaccharide, chondroitin sulfate, was selected since previous work has strongly suggested that the enzymes hydrolyzing this polysaccharide are induced in Arctic as well as temperate sediments (Arnosti, 2000, 2004; Brüchert and Arnosti, 2003), providing the means of probing the enzyme-producing capabilities of a microbial community after prolonged incubation at different temperatures, as well as the characteristics of the enzyme itself. By measuring activities of an enzyme produced in direct response to substrate addition, it is possible to determine whether the characteristics of the enzymes produced by a microbial community change as a result of long-term incubation. Moreover, the activity of the enzyme hydrolyzing chondroitin sulfate exhibits psychrophilic characteristics, with the lowest temperature optimum reported to date among enzymes active in marine sediments (Arnosti and Jørgensen, 2003).

Measurements of the initial hydrolytic step were compared with concentrations of dissolved organic carbon (DOC), total dissolved carbohydrates, and volatile fatty acids (VFA), key intermediates in carbon degradation pathways, in order to more closely examine steps preceding terminal remineralization, and to determine their responses to long-term temperature shifts. Long-term responses to different temperature regimes may differ from short-term responses, since an incubation of 24 months is equivalent to many microbial generations, providing the opportunity to observe the consequences of any changes in microbial community function and structure over longer timescales.

\section{METHODS}

\subsection{Sampling and experimental set-up}

Two sets of sediments were collected, one from a permanently cold region (Svalbard, Arctic Ocean, $79^{\circ} 42^{\prime} \mathrm{N}$, $11^{\circ} 05^{\prime} \mathrm{E}$; sediment temperature typically around $0{ }^{\circ} \mathrm{C}$ ) collected in 2004, and sediments from a temperate region (Wadden Sea, German Bight, $53^{\circ} 27^{\prime} \mathrm{N}, 08^{\circ} 07^{\prime} \mathrm{E}$; sediment temperature typically +3 to $+20^{\circ} \mathrm{C}$ ), collected in 2005 . Sampling sites are described in further detail in Robador et al. (2009).

Sediment from both sampling sites was maintained anaerobically in gas-tight bags stored at 0,10 , and $20^{\circ} \mathrm{C}$ after collection. ${ }^{35} \mathrm{~S}$-sulfate reduction rates were measured in these sediments upon collection, and then periodically during the 24 months of incubation, as reported in Robador et al. (2009). Total prokaryotic cell numbers were counted by 4',6-diamidino-2-phenylindole (DAPI) staining. Bacteria, as well as specific groups of sulfate-reducing bacteria (SRB), were quantified using catalyzed reporter deposition fluorescent in situ hybridization (CARD-FISH) at the same time intervals, as reported in Robador et al. (2009). In order to avoid sulfate limitation of carbon remineralization during the 24-month incubation, sulfate was added to the bags to reconstitute in situ concentrations whenever concentrations decreased to 3-5 mM. Extracellular enzymatic hydrolysis rates were measured as a function of tempera- 
ture after 24 months of sediment incubation. Additionally, fresh sediment was collected in 2007 from both sampling sites and used as a reference for temperature responses of enzymatic hydrolysis. The sampling procedure was similar to that described in Robador et al. (2009). Concentrations of VFA, DOC, and total dissolved carbohydrates were measured in fresh sediments as well as in sediments incubated for 24 months.

\subsection{Hydrolysis rate measurements}

Chondroitin sulfate hydrolysis was measured using fluorescently-labeled chondroitin sulfate (sulfated polymer of $N$-acetyl galactosamine and glucuronic acid, $M_{\mathrm{W}}$ $\sim 200$ kDa, Fluka; Arnosti, 1996, 2003). Chondroitin sulfate was labeled by the method of Glabe et al. (1983), as modified by Arnosti (1995, 2003). Sediments from experimental bags were homogenized by manual kneading and diluted 1:1 with anoxic artificial seawater for incubation in a temperature gradient block (see below). Artificial seawater was prepared anaerobically as described by Widdel and Bak (1992). Sediment slurries were purged with $\mathrm{N}_{2}$ and $5 \mathrm{ml}$ of slurry were transferred into Hungate tubes, which were also gassed with $\mathrm{N}_{2}$ according to the Hungate technique (Bryant, 1972) and sealed with butyl rubber stoppers. Hungate tubes containing only anoxic artificial seawater were prepared to serve as thermal controls. Hungate tubes were immediately placed in the wells of the temperature gradient block and pre-incubated for approximately $4 \mathrm{~h}$ to allow them to equilibrate to the block temperatures. The block was cooled to $-1.5^{\circ} \mathrm{C}$ at one end and heated to $+37.4{ }^{\circ} \mathrm{C}$ yielding temperature increments between wells of approximately $1.5^{\circ} \mathrm{C}$. After $4 \mathrm{~h}$, for each experiment chondroitin sulfate (a single concentration of 10-100 $\mu$ l volume) was added to each tube for a final concentration of 25-250 nmol monomer $\mathrm{ml}^{-1}$ sediment. In all cases, the added concentration most probably oversaturated the enzymes such that rates are zero-order with respect to substrate concentration (see Arnosti 1995, for further discussion).

After an incubation period of $63 \mathrm{~h}$ for the Arctic and 6$24 \mathrm{~h}$ for the temperate sediments, the tubes were centrifuged and porewater was filtered through $0.2 \mu \mathrm{m}$ pore size surfactant-free cellulose acetate syringe filters, then frozen and stored at $-20{ }^{\circ} \mathrm{C}$ until further processing. Incubation times for Arctic sediments were selected based on previous experiments (Arnosti and Jørgensen, 2003). Several incubation times were tested for temperate sediments. In order for activity to be detected, a fraction of the added substrate must be hydrolyzed to molecular weights within the size resolution range of the gel permeation chromatography system. Since enzyme activities vary as a function of temperature, substrate hydrolysis for temperate sediments incubated at 10 and $20^{\circ} \mathrm{C}$ was essentially complete at the temperatures bracketing the optimum temperature $\left(T_{\text {opt }}\right)$ by the time activities were detected at lower temperatures. This phenomenon accounts for the flattened shape of the $T_{\text {opt }}$ for temperate sediments incubated at 10 and $20^{\circ} \mathrm{C}$; samples incubated for $10 \mathrm{~h}$ showed a sharper $T_{\text {opt }}$ at $30{ }^{\circ} \mathrm{C}$, but hydrolysis particularly at temperatures below $15^{\circ} \mathrm{C}$ was not well resolved. Changes in the size distribution of the fluorescently labeled chondroitin sulfate relative to a killed (autoclaved) control were determined using gel permeation chromatography. Hydrolysis rates were calculated from the changes in size distribution, as described in Arnosti (2003). Triplicate tubes were incubated in parallel wells (at the same temperature) at four points along the temperature gradient block in order to investigate reproducibility of hydrolysis rates. All data (including replicate measurements) are shown in Figs. 1 and 2.

\subsection{Carbohydrate concentration measurements}

Carbohydrate concentrations in porewater were analyzed using the 2,4,6 tripyridyl-s-triazine (TPTZ) method (Myklestad et al., 1997). Total carbohydrates were measured after acid hydrolysis to convert combined carbohydrates to monosaccharides. Following the hydrolysis procedure of Burdige et al. (2000), samples were amended with $\mathrm{H}_{2} \mathrm{SO}_{4}$ to a final concentration of $1.2 \mathrm{M}$, heated to $100{ }^{\circ} \mathrm{C}$ for $3 \mathrm{~h}$, and neutralized with $\mathrm{NaOH}$. Concentrations were calculated from glucose standards that had been subjected to the same hydrolysis protocol. Carbohydrate concentrations are expressed in $\mu \mathrm{M}$ units of carbon, assuming that one carbohydrate represents $6 \mathrm{C}$ atoms (i.e., all carbohydrates are hexoses).

\subsection{Volatile fatty acids (VFA)}

The low-molecular weight fatty acids glycolate, lactate, acetate, formate, propionate, butyrate, and isobutyrate were measured by HPLC as derivatives of 2-nitrophenylhydrazide after pre-column derivatization (Albert and Martens, 1997). Samples for fatty acid analysis were stored in brown Teflon-capped borosilicate glass vials (cleaned and then combusted at $480{ }^{\circ} \mathrm{C}$ for $6 \mathrm{~h}$ ) and kept frozen until analysis. The fatty acids were derivatized with 2-nitrophenylhydrazine and injected onto an HPLC system

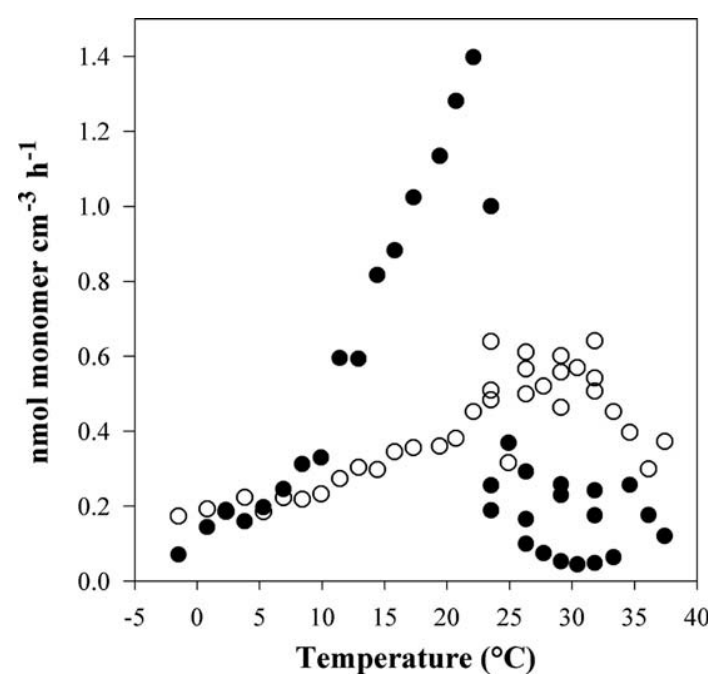

Fig. 1. Hydrolysis rates of chondroitin sulfate determined from the temperature-gradient incubation experiment of fresh Arctic and temperate sediments. 
consisting of a Sykam 1121 HPLC pump, connected to a $20 \times 4 \mathrm{~mm}$ ID LiChrosphere RP-8 $5 \mu \mathrm{m}$ guard column and a $250 \times 4 \mathrm{~mm}$ ID LiChrosphere RP- 8 column, both kept at $25^{\circ} \mathrm{C}$ in a Jetstream Plus column oven. Peaks were
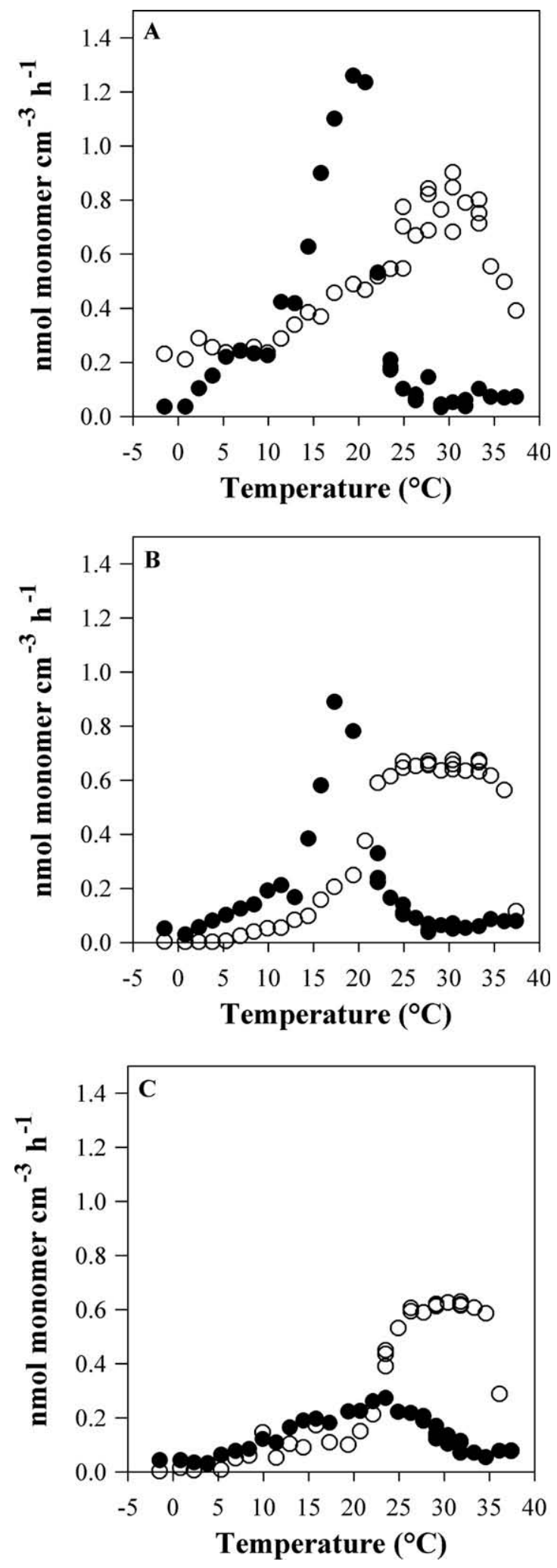

detected with a Linear UVIS UV detector set at $400 \mathrm{~nm}$. Concentrations were determined after calibration with standard mixtures containing glycolate, formate, lactate, acetate, propionate, isobutyrate, butyrate, and valerate. A standard was measured after every fifth sample. The detection limit of the method was $200 \mathrm{nM}$. Integration was performed with a Eurochrom 2000 Integration package.

\subsection{DOC measurements}

DOC concentrations were determined in porewater samples using a Shimadzu TOC 5050A total organic carbon analyzer equipped with an ASI 5000 autosampler (Shimadzu, Kyoto, Japan). In short, diluted samples (1:4) were acidified to $\mathrm{pH} 2$ with $2 \mathrm{M} \mathrm{HCl}$ and purged with $\mathrm{CO}_{2}$-free carrier gas for $5 \mathrm{~min}$ at a flow rate of $125 \mathrm{ml} \mathrm{min}^{-1}$, to remove inorganic carbon, and subsequently combusted to $\mathrm{CO}_{2}$ in the internal furnace, filled with an oxidation catalyst and heated to $680^{\circ} \mathrm{C}$. The combustion products were carried into the detection cell by high purity $\mathrm{CO}_{2}$-free gas through an electronic dehumidifier for removal of water vapor followed by a sub-micron particle filter. $\mathrm{CO}_{2}$ generated from the combusted carbon was detected in a non-dispersive infrared gas analyzer. DOC concentrations of the samples are proportional to the peak area count and are calculated using standard solutions of potassium hydrogen phthalate.

\section{RESULTS}

In fresh sediments, the $T_{\mathrm{opt}}$ of chondroitin sulfate hydrolysis were 22 and $26{ }^{\circ} \mathrm{C}$ for the Arctic and temperate sediments, respectively (Table 1 and Fig. 1). In the Arctic sediments, the hydrolysis rate decreased abruptly above $22.1{ }^{\circ} \mathrm{C}$ from $1.4 \mathrm{nmol}$ monomer $\mathrm{cm}^{-3} \mathrm{~h}^{-1}$ to $0.2-0.4 \mathrm{nmol}$ monomer $\mathrm{cm}^{-3} \mathrm{~h}^{-1}$, whereas in the temperate sediments the $T_{\text {opt }}$ was broader and the rate at the $T_{\text {opt }}$ was only $0.6 \mathrm{nmol}$ monomer $\mathrm{cm}^{-3} \mathrm{~h}^{-1}$. After 24 months, the $T_{\text {opt }}$ of Arctic sediments incubated at 0,10 , and $20^{\circ} \mathrm{C}$ were 19.4 , 17.3 , and $23.5^{\circ} \mathrm{C}$, respectively, little different from the initial conditions (Table 1 and Fig. 2). Compared to the fresh sediment, rates of hydrolysis at $T_{\mathrm{opt}}$ after 24 months of incubation were similar at $0{ }^{\circ} \mathrm{C}(1.4$ and $1.3 \mathrm{nmol}$ monomer $\mathrm{cm}^{-3} \mathrm{~h}^{-1}$, respectively), but decreased to $0.9 \mathrm{nmol}$ $\mathrm{cm}^{-3} \mathrm{~h}^{-1}$ for sediment incubated at $10^{\circ} \mathrm{C}$, and to $0.3 \mathrm{nmol}$ monomer $\mathrm{cm}^{-3} \mathrm{~h}^{-1}$ for sediments incubated at $20^{\circ} \mathrm{C}$. The temperature response of chondroitin sulfate hydrolysis for the Arctic sediments incubated for 24 months thus showed a decrease in the maximum rate, but an overall similar temperature profile.

For the temperate sediments, higher incubation temperatures did not change the $T_{\text {opt }}$, which remained in the range of 30.4-31.8 ${ }^{\circ} \mathrm{C}$ for all treatments (Table 1 and Fig. 2). The need for longer incubation times to detect activity at tem-

Fig. 2. Hydrolysis rates of chondroitin sulfate determined from the temperature-gradient incubation experiment for the Arctic and temperate sediments after 24 months of incubation at (A) $0{ }^{\circ} \mathrm{C}$, (B) $10{ }^{\circ} \mathrm{C}$ and $(\mathrm{C}) 20^{\circ} \mathrm{C}$. 
Table 1

Hydrolysis activities determined in the temperature-gradient incubations.

\begin{tabular}{|c|c|c|c|c|}
\hline Sediment type & $\begin{array}{l}\text { Incubation time } \\
\text { (months) }\end{array}$ & $\begin{array}{l}\text { Incubation temperature } \\
\left({ }^{\circ} \mathrm{C}\right)\end{array}$ & $\begin{array}{l}\text { Maximum hydrolysis rates (nmol } \\
\text { monomer } \mathrm{cm}^{-3} \mathrm{~h}^{-1} \text { ) }\end{array}$ & $T_{\text {opt }}{ }^{\mathrm{a}}\left({ }^{\circ} \mathrm{C}\right)$ \\
\hline \multirow[t]{4}{*}{ Arctic } & Fresh & 0 & 1.4 & 22.1 \\
\hline & & 0 & 1.3 & 19.4 \\
\hline & 24 months & 10 & 0.9 & 17.3 \\
\hline & & 20 & 0.3 & 23.5 \\
\hline \multirow[t]{4}{*}{ Temperate } & Fresh & 10 & 0.6 & 31.8 \\
\hline & & 0 & 0.9 & 30.4 \\
\hline & 24 months & 10 & 0.7 & 30.4 \\
\hline & & 20 & 0.6 & 31.8 \\
\hline
\end{tabular}

${ }^{a}$ Temperature at which maximum hydrolysis rates were measured.

peratures below $15^{\circ} \mathrm{C}$ flattened the profile near the $T_{\text {opt }}$ for sediments incubated at $10^{\circ} \mathrm{C}$ and $20^{\circ} \mathrm{C}$ (see Section 2). After 24 months of incubation at $0^{\circ} \mathrm{C}$, hydrolysis rates at the $T_{\text {opt }}$ were on average slightly higher compared to the fresh sediment, but remained nearly unchanged in the 10 and $20^{\circ} \mathrm{C}$ incubations (Table 1 and Fig. 2). Sediments incubated for 24 months at 10 and $20^{\circ} \mathrm{C}$, however, had lower hydrolysis rates in the range $0-15^{\circ} \mathrm{C}$ compared to sediments that had been incubated at $0{ }^{\circ} \mathrm{C}$ for 24 months.

\subsection{Dissolved porewater constituents}

Concentrations of DOC were quite similar in fresh Arctic and temperate sediments, $2701 \mu \mathrm{M} \mathrm{C}$ and $2256 \mu \mathrm{M} \mathrm{C}$, respectively. After 24 months of incubation, DOC concentrations increased in proportion to incubation temperature (Fig. 3). At $20^{\circ} \mathrm{C}$, DOC in Arctic and temperate sediments was more than three times higher than in the fresh sediment, $9490 \mu \mathrm{M} \mathrm{C}$ in Arctic sediments and $7002 \mu \mathrm{M} \mathrm{C}$ in temperate sediments (Fig. 3).
Contributions of total carbohydrates to DOC differed between the Arctic and temperate sediments (Fig. 3). In Arctic sediment, total carbohydrates initially constituted $2.9 \%$ of DOC, whereas the average initial concentrations of total carbohydrates in temperate sediments were $28 \%$ of DOC. The contribution of carbohydrates to DOC increased systematically with increasing temperature in Arctic and temperate sediments. Total dissolved carbohydrates in Arctic sediments constituted $14 \%$ of DOC after 24 months at $20{ }^{\circ} \mathrm{C}$ (Fig. 3). In the temperate sediment, the contribution of carbohydrates to DOC was highest at the highest incubation temperature $(32 \%)$. The dissolved carbohydrate concentrations therefore increased in both absolute and relative terms at higher incubation temperatures.

VFA concentrations were low irrespective of the differences observed with varying temperatures (Fig. 4). Only lactate, acetate and formate were present in quantifiable concentrations (Fig. 4). Propionate, isobutyrate and valerate were also detected but at concentrations too close to the detection limit $(200 \mathrm{nM})$ for accurate quantification.
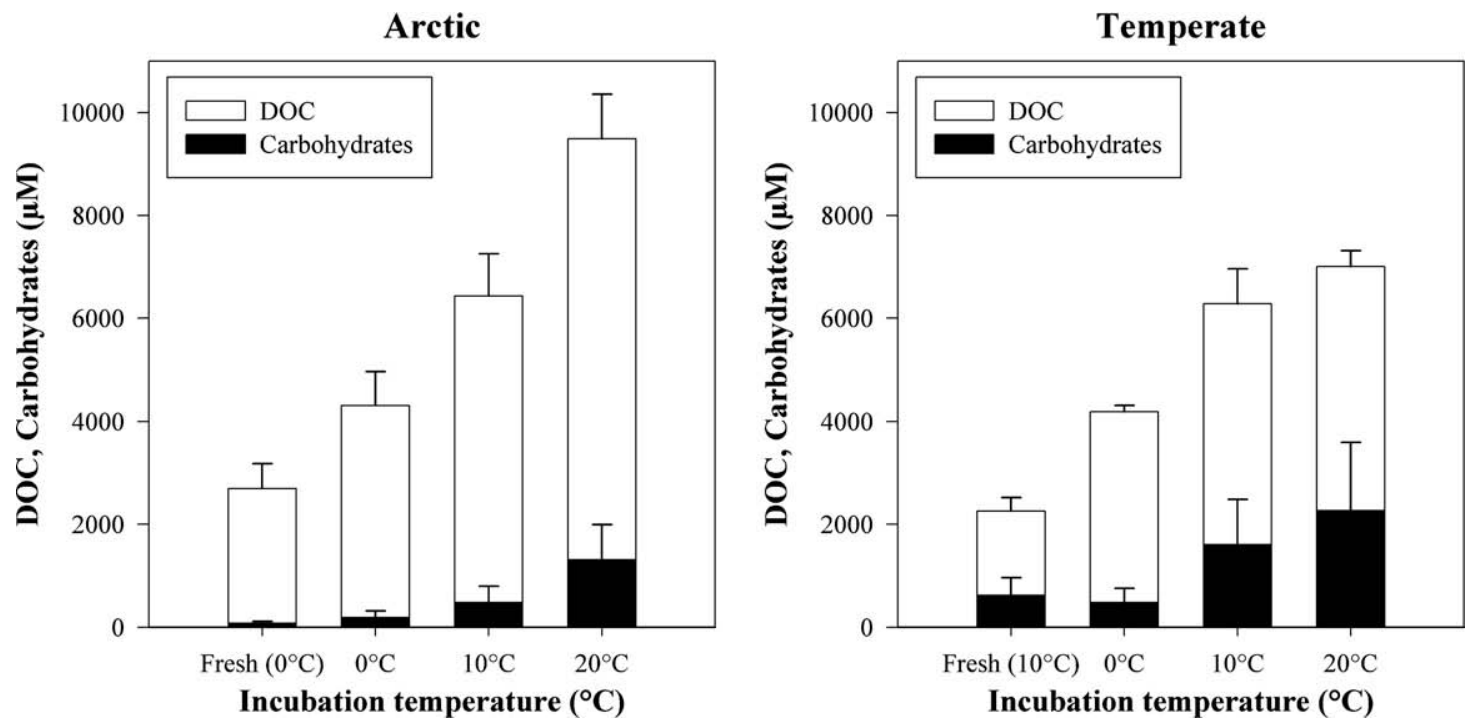

Fig. 3. Dissolved organic carbon (DOC) and dissolved carbohydrate concentrations in fresh sediments and in the 0,10 , and $20{ }^{\circ} \mathrm{C}$ experiment bags after 24 months of incubation of the Arctic and the temperate sediment. Bars show mean values and deviations of duplicate measurements of DOC. Measurements of dissolved carbohydrates were made in triplicate; bars show standard deviations in measurements of dissolved carbohydrates. 

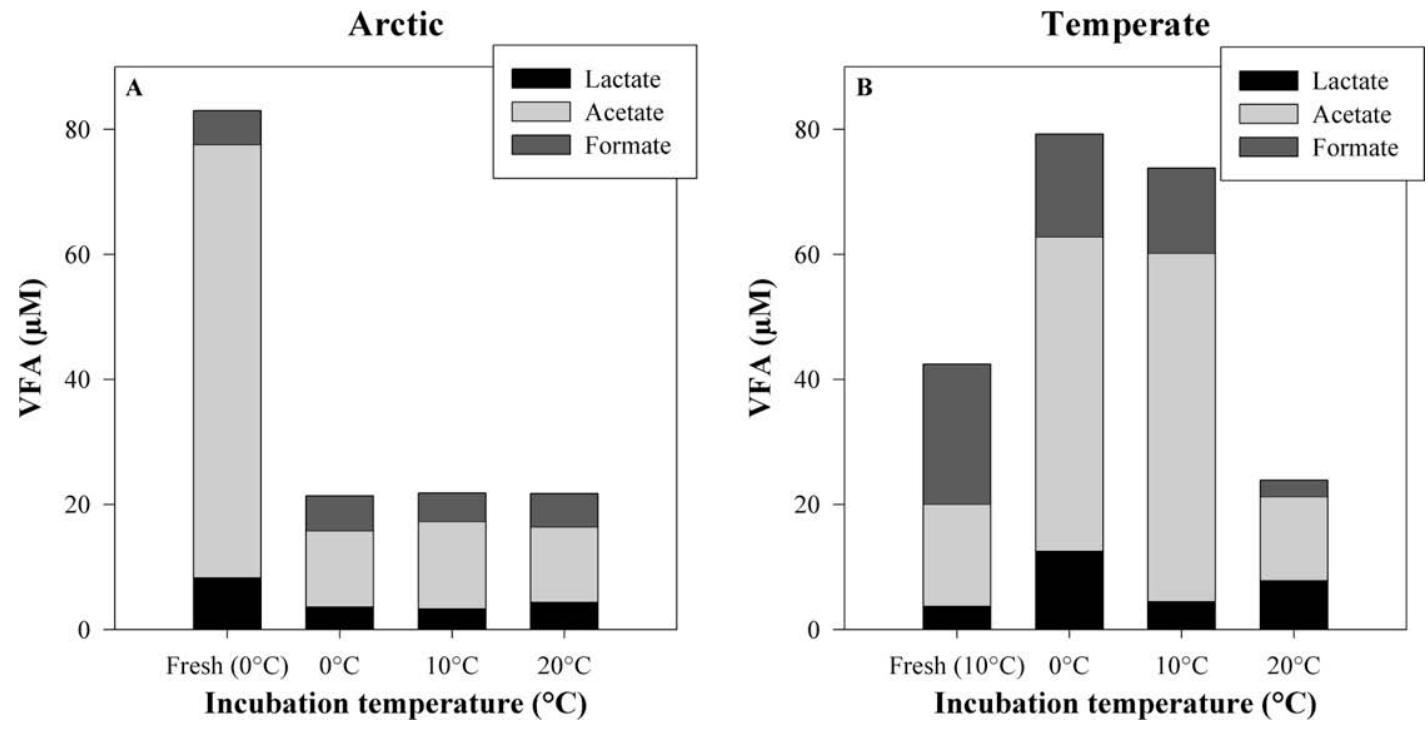

Fig. 4. Volatile fatty acid concentrations in the fresh sediments and in the 0,10 and $20{ }^{\circ} \mathrm{C}$ experimental bags after 24 months of incubation of (A) the Arctic and (B) the temperate sediment. Error bars show mean values of duplicate measurements.

In the Arctic sediment, concentrations of all VFA's including acetate were higher in the fresh sediments than after 24 months (Fig. 4A). In temperate sediment, concentrations of formate in fresh sediments and of acetate after 24 months of incubation at 0 and $10{ }^{\circ} \mathrm{C}$ were also relatively higher. VFA's, however, represented just a small portion of DOC (between $0.2 \%$ and $3 \%$ ).

\section{DISCUSSION}

\subsection{Temperature response of enzymatic hydrolysis to long- term incubation}

Measurements of hydrolysis rates as a function of temperature can yield basic information about the characteristics of enzymes, including $T_{\text {opt }}$. This approach is a valuable means of probing the role of enzymes in organic carbon degradation, since individual hydrolytic enzymes have so far not been isolated from sediments, thereby precluding specific biochemical measurements. Since the identities of organisms producing extracellular enzymes in sediments are largely unknown, molecular techniques cannot be used to investigate the relationship between microbial community structure and enzyme activities.

Although the $T_{\text {opt }}$ of some extracellular enzymes exceeds the $T_{\text {opt }}$ for growth of the organisms and even the temperature at which the organisms can survive (Feller et al., 1992; Burini et al., 1994), $T_{\text {opt }}$ is a useful parameter to characterize enzymes in the environment, since psychrophilic organisms typically express enzymes with lower $T_{\text {opt }}$ than do closely-related mesophilic organisms (Feller and Gerday, 2003). Moreover, changes in enzyme $T_{\text {opt }}$ imply changes in the structural characteristics of enzymes such as thermal stability (D'Amico et al., 2002). After incubation at 0, 10, and $20{ }^{\circ} \mathrm{C}$, the $T_{\text {opt }}$ of extracellular enzymatic hydrolysis changed little, with Arctic sediments showing a $T_{\text {opt }}$ of 17.3-23.5 ${ }^{\circ} \mathrm{C}$ (Table 1 and Fig. 2). The $T_{\text {opt }}$ range and the shape of the temperature response profile for the Arctic sediments is close to that reported (ca. $15-18^{\circ} \mathrm{C}$ ) in a previous investigation of chondroitin hydrolysis in Arctic sediments collected from a different fjord in Svalbard (Arnosti and Jørgensen, 2003). Temperate sediments showed a considerably higher $T_{\text {opt }}$ centered around $30^{\circ} \mathrm{C}$ (Table 1 and Fig. 2). The persistence of the $T_{\text {opt }}$ suggests that the temperature characteristics of the extracellular enzymes produced in these sediments in response to the addition of chondroitin sulfate were more closely related to the original temperature of the sediment than to the temperature of sediment incubation, and the nature of this response changed little after 24 months of incubation.

The consistency in temperature response of enzymatic hydrolysis after long-term incubation contrasts with the response observed for sulfate reduction in Arctic sediments. After 24 months of incubation at 10 and $20^{\circ} \mathrm{C}$, the temperature optimum of sulfate reduction increased by 5 and $8^{\circ} \mathrm{C}$ in Arctic sediments, respectively, relative to the $0{ }^{\circ} \mathrm{C}$ incubation (Robador et al., 2009). The temperature response of temperate sediments, however, remained unchanged after 24 months incubation at 0,10 , and $20^{\circ} \mathrm{C}$. The change in temperature response of sulfate reduction for the Arctic sediments was also accompanied by a shift in the community composition of sulfate reducers, as demonstrated by CARD-FISH, whereas the temperate sediments showed no change (Robador et al., 2009).

Arctic sediments incubated for 24 months at $0{ }^{\circ} \mathrm{C}$ showed little difference in hydrolysis rates at the $T_{\text {opt }}$ relative to fresh sediments (Table 1 and Fig. 2). At elevated temperatures, however, potential hydrolysis rates measured at $T_{\text {opt }}$ declined, suggesting that either the absolute quantity or the catalytic efficiency of enzymes produced in response to substrate addition (and incubation in the temperature gradient block) had changed relative to sediments incubated at $0{ }^{\circ} \mathrm{C}$. Such a decline could be due to decreasing numbers of organisms capable of producing suitable extra- 
cellular enzymes. Cell counts support this possibility, since the microbial populations of Arctic sediments incubated at 10 and $20{ }^{\circ} \mathrm{C}$ for 24 months declined, $17-46 \%$, respectively, relative to initial numbers (Fig. 5).

For temperate sediments, hydrolysis rates at the $T_{\mathrm{opt}}$ were similar for the fresh sediments and sediments incubated for 24 months (Table 1 and Fig. 2). This consistency could be due to the fact that the experimental temperature span was within the natural temperature range of these sediments. Although cell counts did not decline greatly over time in the temperate sediment (Fig. 5), absolute hydrolysis rates at the lower end of the temperature range were affected by prolonged incubation at higher temperatures. Sediments incubated for 24 months at 10 and $20^{\circ} \mathrm{C}$ and then incubated briefly $(24 \mathrm{~h})$ in the temperature gradient block at temperatures below $10^{\circ} \mathrm{C}$ were considerably lower than rates measured in sediments incubated for 24 months at $0{ }^{\circ} \mathrm{C}$. This difference was even discernable for the hydrolysis rates up to $20^{\circ} \mathrm{C}$, suggesting that prolonged incubation at elevated temperature adversely affected the lowtemperature capacity of the microbial community to respond to substrate addition.

\subsection{Carbon cycling under changed temperature regimes: evidence of decoupling}

Long-term incubation at temperatures of 0,10 , and $20{ }^{\circ} \mathrm{C}$ facilitates comparison of the temperature dependency of different steps in carbon remineralization pathways, and their effects on carbon inventories in Arctic and in temperate sediments. Investigations of carbon cycling pathways are limited in part by our inability as a community to measure specific processes with precision, including turnover times of many intermediate pools. Nonetheless, a compari- son of the rates of initial and terminal steps in anaerobic carbon cycling with the concentrations of intermediate pools reveals information about possible rate-limiting steps in carbon transformations.

A comparison of DOC concentrations in fresh sediments with the sediments incubated for 24 months shows clear signs of changes in carbon transformation pathways. DOC is a critical intermediate, since DOC concentrations reflect the net balance between solubilization/hydrolysis of particulate organic carbon (POC) and consumption of DOC via transformation (e.g., hydrolysis of high-molecular weight DOC to low-molecular weight DOC, fermentation of low-molecular weight DOC to VFA's) and terminal oxidation (Fig. 6). DOC concentrations in fresh sediments are consistent with previously published data on sediment porewater concentrations from muddy coastal and continental shelf environments (e.g., Alperin et al., 1999; Arnosti and Holmer, 1999; Burdige et al., 2000). The elevated concentrations of DOC in sediments incubated for 24 months, in particular the high concentrations of DOC at elevated incubation temperature (Figs. 4 and 6, boxes 2 and $2^{\prime}$ and arrow $\mathrm{B}^{\prime}$ ), provide strong evidence of changes in carbon processing in both Arctic and temperate sediments.

Increases in DOC concentrations in response to temperature changes have been reported previously, but these increases have been transitory or were only examined over short periods of time. Seasonally increasing temperatures coincided with accumulation of porewater DOC and depletion of porewater sulfate in organic-rich coastal sediments from a temperate environment (Alperin et al., 1994). Within a few weeks, however, the high concentrations (up to $8 \mathrm{mM}$ ) of DOC were consumed by the terminal oxidizing community, and DOC concentrations returned to $2-3 \mathrm{mM}$. In Arctic sediments, substrate addition and/or homogenization

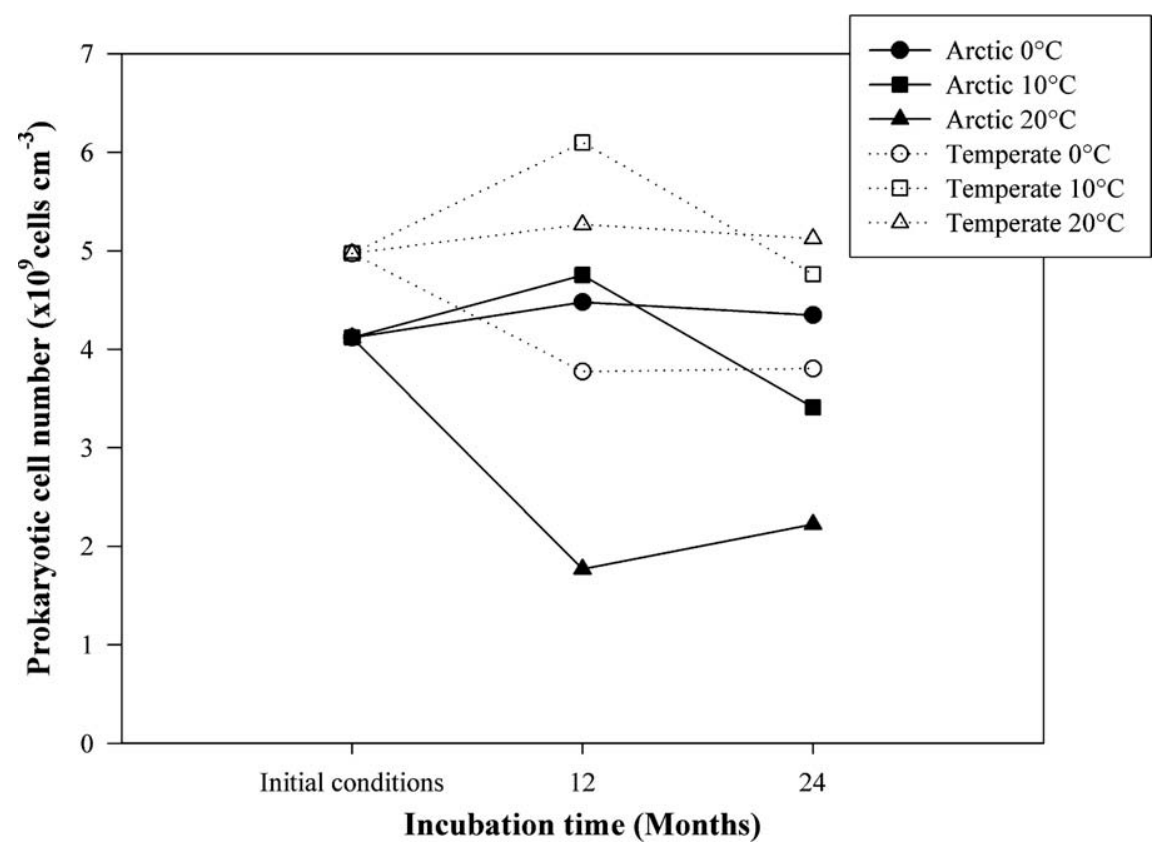

Fig. 5. Total prokaryotic cell numbers (DAPI staining) in Arctic and temperate sediments during the 24 month time course of sediment incubation. Data from Robador et al. (2009). 


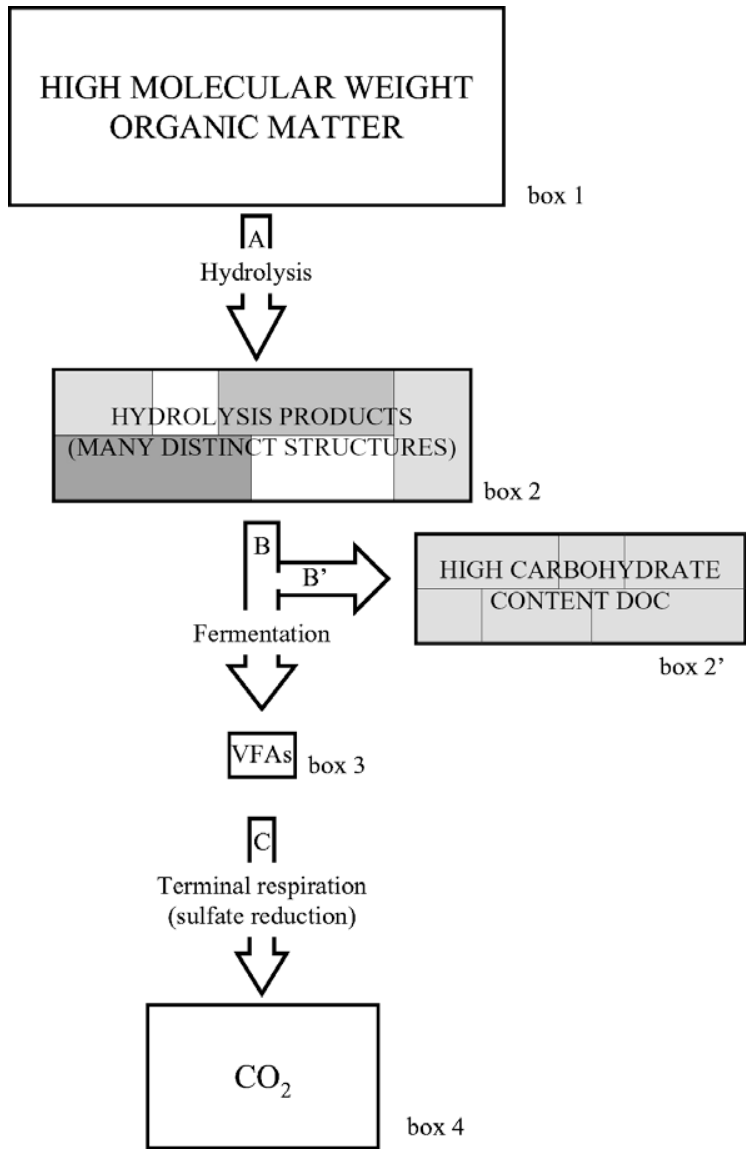

Fig. 6. Conceptual model of carbon degradation, illustrating buildup of high carbohydrate-content, fermentation-resistant DOC. Divisions in boxes 2 and $2^{\prime}$ indicate different size classes, different shades indicate compositions.

also led to transient buildup of DOC constituents such as VFA (Brüchert and Arnosti, 2003; Arnosti et al., 2005), but within days to weeks, the accumulated DOC was consumed again. Short-term experiments with substrateamended coastal sediments also showed that production and consumption of DOC can become unbalanced over the temperature range typically experienced by temperate sediments (Weston and Joye, 2005).

High concentrations of DOC in sediments that have been incubated at stable temperatures for 24 months thus demonstrate that the balance between DOC production and consumption has changed in more than a transient manner (Fig. 6: flow via arrows $\mathrm{B}$ and $\mathrm{B}^{\prime}$ has changed, box $2^{\prime}$ increases in size.) Refractory carbohydrates constitute a significant portion of this DOC increase. Their contribution to DOC increased with increasing temperature in Arctic and in temperate sediments (Figs. 3 and 6, box $\left.2^{\prime}\right)$. VFA, in contrast, contributed a very low $(0.2-3 \%)$ and relatively constant fraction to DOC in both sediment types (Figs. 4 and 6, box 3 ).

The accumulation of DOC shows that conversion of POC to DOC continued in these sediments (Fig. 6, arrow A); increasing relative and absolute concentrations of carbohydrates (Fig. 6, boxes 2 and $2^{\prime}$ ) indicated that substrates broadly suitable for fermentation should have been available to the microbial community. In fact, a comparison of sulfate reduction rates at 0,10 , and $20^{\circ} \mathrm{C}$ with inventories of VFA and DOC suggest that downstream carbon processing was increasingly decoupled from the initial hydrolytic step at elevated temperatures. Sulfate reduction rates in the Arctic and temperate sediments incubated for 24 months at 0 and $10^{\circ} \mathrm{C}$ showed a two- to fourfold decrease relative to the initial conditions and an even greater decline, with respect to the initial increase, after incubation for 24 months at $20^{\circ} \mathrm{C}$ (Fig. 6, rate at arrow $\mathrm{C}$ decreasing; Fig. 7). The decreased sulfate reduction rates are most likely due to substrate limitation for sulfate-reducing bacteria, since sulfate was not limiting and these rates reflect in part the availability of substrates suitable to fuel sulfate reduction.

An alternative explanation might be that sulfate-reducing bacteria were less able to tolerate long-term exposure to higher temperatures than other members of the microbial food chain. In fact, increasing incubation temperatures had a strong impact in Arctic sediments as demonstrated by the temperature sensitivity exhibited by the microbial SRB community and the decline of specific groups of SRB identified by CARD-FISH (Robador et al., 2009). However, the fact that a similarly sharp decline in sulfate reduction rates was also observed for the temperate sediments (Fig. 7), where neither total prokaryotic cell counts nor CARDFISH counts for bacteria or sulfate reducers decreased significantly (Fig. 5; Robador et al., 2009) suggest that microbially limited substrate transformation was the overriding cause for the decline in sulfate reduction rates in the Arctic and temperate sediments.

All the VFA detected in this study constitute major substrates for sulfate-reducing bacteria (Sørensen et al., 1981; Fukui et al., 1997). Low concentrations (Figs. 4 and 6, small size of box 3 ) indicate that the balance between production of these intermediates and their consumption was maintained at all temperatures. Specific inhibition experiments of sulfate reduction typically result in increasing VFA concentrations reaching over $1500 \mu \mathrm{M}$ (Finke et al., 2007), between one and two orders of magnitude greater than the values measured in this study. If sulfate-reducing bacteria were more intolerant to higher temperatures than fermenting bacteria, VFA concentrations should have increased well above the $20-80 \mu \mathrm{M}$ concentrations shown in Fig. 4 (Fig. 6, box 3 should have increased in size). In addition, previous investigations with comparable sediments from Svalbard have shown a close coupling between fermentation and sulfate reduction sustained over a broad temperature range of $0{ }^{\circ} \mathrm{C}$ to $25-30{ }^{\circ} \mathrm{C}$ (Finke and Jørgensen, 2008). Together these data imply that carbon limitation of sulfate reduction occurred at or before the fermentative step (Fig. 6, limitation prior to box 3).

The accumulation of DOC resistant to transformation or uptake is also in accordance with observations of DOC generated in short experiments conducted with coastal temperate sediments (Weston and Joye, 2005). In that study, passage of artificial anoxic porewater through bioreactors filled with temperate sediments collected at different seasons and incubated at the in situ temperatures of $12-29^{\circ} \mathrm{C}$ 


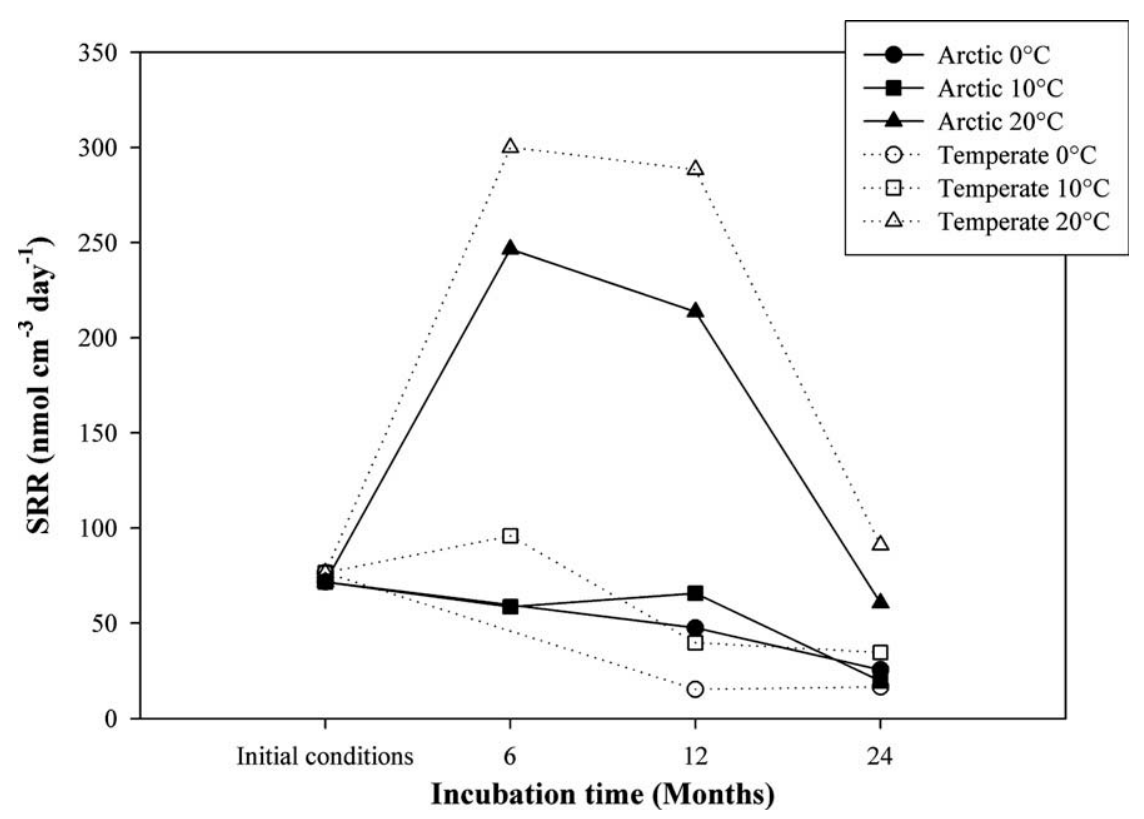

Fig. 7. Sulfate reduction rates in Arctic and temperate sediments incubated at 0,10 , and $20^{\circ} \mathrm{C}$ for 24 months. Data from Robador et al. (2009).

yielded an outflow of DOC from the bioreactors. Less than half of the DOC generated within the bioreactors was remineralized by sulfate reducers, leading Weston and Joye (2005) to conclude that the DOC was refractory, on the 10-day timescale of the experiment. Although the bioreactor experiments could not be used to distinguish between hydrolytic and fermentative steps, the data from our temperate and Arctic sediments suggest that the 'sticking point' might be found within the fermentative community.

An inability to ferment a growing fraction of the DOC pool to VFA's (Fig. 6, flow via arrow $\mathrm{B}^{\prime}$ rather than arrow B) could be due to the production of refractory DOC, or to production of DOC that is intrinsically difficult to transport across the cell membrane, even though it may be within the direct uptake size limit. A rarely-addressed but possibly critical problem may relate to substrate transport: once a substrate is of sufficiently small size, it still needs to pass through a microbial porin (the water-filled inlet channels spanning the outer membrane of gram-negative bacteria). The structure of these porins represents an additional aspect of substrate selectivity. Work with enrichment cultures of anaerobic marine bacteria has demonstrated that there may be difficulties in uptake by sedimentary microbial communities of selected disaccharides that are within the size limit for direct transport (Arnosti and Repeta, 1994). These difficulties could be related to discrimination among solutes by general uptake porins: solute uptake rates across general uptake porins may vary by an order of magnitude based on solute charge or hydrophobicity (Delcour, 2003), and can also vary with specific structural features, as discussed by Arnosti and Repeta (1994).

An additional possibility is the alteration of otherwise bioavailable DOC to DOC that is difficult to hydrolyze further. A model encompassing this idea has been proposed by Burdige and Gardner (1998) and discussed further by Bur- dige (2001), who suggest that the porewater size/reactivity model can account for the distribution of a relatively unreactive pool of lower molecular weight (below ca. $3 \mathrm{kDa}$ ) DOC in sediments. Specific characteristics and/or mechanisms operating in sediments that contribute to this pool remain elusive, but investigations of DOC in seawater provide possible insights. For example, structural alterations such as methylation of protein have been shown to impede uptake yet allow for hydrolysis (Keil and Kirchman, 1992), and exposure of DOC to microbial remineralization has been found to increase resistance of otherwise labile protein (Keil and Kirchman, 1994). Furthermore, Nagata and Kirchman (1996) hypothesized that adsorption processes of polymeric organic matter to colloids may lead to the formation of a semi-labile DOC pool which can result in the decoupling of DOC production and rapid bacterial mineralization and, therefore, a net accumulation of recalcitrant DOC (Fig. 6, increasing sizes of boxes 2 and $2^{\prime}$ ).

\section{CONCLUSIONS}

Prolonged incubations, particularly at elevated temperatures, had differential effects on sedimentary microbial communities. The community of organisms producing extracellular enzymes continued to be responsive to additional substrates and substrates present in the sediment, as demonstrated by induced hydrolysis of chondroitin sulfate and increased sedimentary concentrations of DOC and dissolved carbohydrates. Accumulation of DOC demonstrated that the activities of organisms and enzymes responsible for the solubilization/hydrolysis of POC to DOC outpaced DOC consumption by sulfate reducers. Low concentrations of volatile fatty acids and temperature-related decline in sulfate reduction rates demonstrate close coupling between sulfate reduction and the produc- 
tion of volatile fatty acids, such that the sulfate-reducing community became increasingly substrate-limited, despite the presence of abundant DOC. The extent to which this roadblock in carbon transformation might reflect an inability of the fermentative community to grow or whether the intermediate transformation products of DOC could not be transformed further because of structural limitations remains to be determined. Since these effects occurred both in temperate and Arctic sediments, they may reflect a general characteristic of microbial communities responding to longterm temperature changes. As environmental temperature changes in Arctic and in temperate environments, the balance of microbial remineralization processes may also shift. Further study of the long-term stability of the accumulating dissolved organic carbon is important to understand the overall significance of warming sediments in the marine carbon cycle.

\section{ACKNOWLEDGMENTS}

We thank Martina Meyer for the assistance in the lab and captain Stig Henningsen and John Mortensen of MS FARM for the successful cruise in Svalbard. We also thank two anonymous reviewers for thoughtful comments. This study was supported by the Max Planck Society and by the German Research Foundation through the Priority Program 1162 'The impact of climate variability on aquatic ecosystems (AQUASHIFT) BR 2174-1-1'. Funding was also provided to C.A. by the National Science Foundation (OCE-0323975; OCE-0848703) and to A.S. by the United States Environmental Protection Agency (EPA) under the Science to Achieve Results (STAR) Graduate Fellowship Program.

\section{REFERENCES}

Albert D. B. and Martens C. S. (1997) Determination of lowmolecular-weight organic acid concentrations in seawater and pore-water samples via HPLC. Mar. Chem. 56, 27-37.

Alperin M. J., Albert D. B. and Martens C. S. (1994) Seasonal variations in production and consumption rates of dissolved organic carbon in an organic-rich coastal sediment. Geochim. Cosmochim. Acta 58, 4909-4930.

Alperin M. J., Martens C. S., Albert D. B., Suayah I. B., Benninger L. K., Blair N. E. and Jahnke R. A. (1999) Benthic fluxes and porewater concentration profiles of dissolved organic carbon in sediments from the North Carolina continental slope. Geochim. Cosmochim. Acta 63, 427-448.

Anisimov O. A., Vaughan D. G., Callaghan T. V., Furgal C., Marchant H., Prowse T. D., Vilhjálmsson H. and Walsh J. E. (2007) Polar regions (Arctic and Antarctic). In Climate Change 2007: Impacts, Adaptation and Vulnerability. Contribution of Working Group II to the Fourth Assessment Report of the Intergovernmental Panel on Climate Change (eds. M. L. Parry, O. F. Canziani, J. P. Palutikof, P. J. van der Linden and C. E. Hanson). Cambridge University Press, Cambridge, pp. 653685.

Arnosti C. (1995) Measurement of depth-related and site-related differences in polysaccharide hydrolysis rates in marine-sediments. Geochim. Cosmochim. Acta 59, 4247-4257.

Arnosti C. (1996) A new method for measuring polysaccharide hydrolysis rates in marine environments. Org. Geochem. 25, $105-115$.

Arnosti C. (2000) Substrate specificity in polysaccharide hydrolysis: contrasts between bottom water and sediments. Limnol. Oceanogr. 45, 1112-1119.
Arnosti C. (2003) Fluorescent derivatization of polysaccharides and carbohydrate-containing biopolymers for measurement of enzyme activities in complex media. J. Chromatogr. B 793, 181191.

Arnosti C. (2004) Speed bumps and barricades in the carbon cycle: substrate structural effects on carbon cycling. Mar. Chem. 92, 263-273.

Arnosti C. and Repeta D. J. (1994) Oligosaccharide degradation by anaerobic marine bacteria: characterization of an experimental system to study polymer degradation in sediments. Limnol. Oceanogr. 39, 1865-1877.

Arnosti C. and Holmer M. (1999) Carbohydrate dynamics and contributions to the carbon budget of an organic-rich coastal sediment. Geochim. Cosmochim. Acta 63, 393-403.

Arnosti C. and Holmer M. (2003) Carbon cycling in a continental margin sediment: contrasts between organic matter characteristics and remineralization rates and pathways. Estuar. Coast. Shelf Sci. 58, 197-208.

Arnosti C. and Jørgensen B. B. (2003) High activity and low temperature optima of extracellular enzymes in Arctic sediments: implications for carbon cycling by heterotrophic microbial communities. Mar. Ecol. Prog. Ser. 249, 15-24.

Arnosti C. and Jørgensen B. B. (2006) Organic carbon degradation in arctic marine sediments, Svalbard: a comparison of initial and terminal steps. Geomicrobiol. J. 23, 551-563.

Arnosti C., Jørgensen B. B., Sagemann J. and Thamdrup B. (1998) Temperature dependence of microbial degradation of organic matter in marine sediments: polysaccharide hydrolysis, oxygen consumption, and sulfate reduction. Mar. Ecol. Prog. Ser. 165, 59-70.

Arnosti C., Finke N., Larsen O. and Ghobrial S. (2005) Anoxic carbon degradation in Arctic sediments: microbial transformations of complex substrates. Geochim. Cosmochim. Acta 69, 2309-2320.

Belicka L. L., Macdonald R. W. and Harvey H. R. (2002) Sources and transport of organic carbon to shelf, slope, and basin surface sediments of the Arctic Ocean. Deep-Sea Res. Part I 49, 1463-1483.

Benz R. and Bauer K. (1988) Permeation of hydrophilic molecules through the outer-membrane of gram-negative bacteria: review on bacterial porins. Eur. J. Biochem. 176, 1-19.

Brüchert V. and Arnosti C. (2003) Anaerobic carbon transformation: experimental studies with flow-through cells. Mar. Chem. 80, 171-183.

Bryant M. P. (1972) Commentary on hungate technique for culture of anaerobic bacteria. Am. J. Clin. Nutr. 25, 1324-1328.

Burdige D. J. (2001) Dissolved organic matter in Chesapeake Bay sediment pore waters. Org. Geochem. 32, 487-505.

Burdige D. J. and Gardner K. G. (1998) Molecular weight distribution of dissolved organic carbon in marine sediment pore waters. Mar. Chem. 62, 45-64.

Burdige D. J., Skoog A. and Gardner K. (2000) Dissolved and particulate carbohydrates in contrasting marine sediments. Geochim. Cosmochim. Acta 64, 1029-1041.

Burini J. F., Gugi B., Merieau A. and Guespinmichel J. F. (1994) Lipase and acidic phosphatase from the psychrotrophic bacterium Pseudomonas fuorescens: two enzymes whose synthesis is regulated by the growth temperature. FEMS Microbiol. Lett. 122, 13-18.

Canfield D. E., Jørgensen B. B., Fossing H., Glud R., Gunderse J., Ramsing N. B., Thamdrup B., Hansen J. W., Nielsen L. P. and Hall P. O. J. (1993) Pathways of organic-carbon oxidation in three continental-margin sediments. Mar. Geol. 113, 27-40.

Capone D. G. and Kiene R. P. (1988) Comparison of microbial dynamics in marine and fresh-water sediments: contrasts in anaerobic carbon catabolism. Limnol. Oceanogr. 33, 725-749. 
D’Amico S., Claverie P., Collins T., Georlette D., Gratia E., Hoyoux A., Meuwis M.-A., Feller G. and Gerday C. (2002) Molecular basis of cold adaptation. Philos. Trans. B 357, 917925.

Delcour A. H. (2003) Solute uptake through general porins. Front. Biosci. 8, 1055-1071.

Denman K. L., Brasseur G., Chidthaisong A., Ciais P., Cox P. M., Dickinson R. E., Hauglustaine D., Heinze C., Holland E., Jacob D., Lohmann U., Ramachandran S., da Silva Dias P. L., Wofsy S. C. and Zhang X. (2007) Couplings between changes in the climate system and biogeochemistry. In Climate Change 2007: The Physical Science Basis. Contribution of Working Group I to the Fourth Assessment Report of the Intergovernmental Panel on Climate Change (eds. S. D. Solomon, M. Qin, Z. Manning, M. Chen, K. B. Marquis, M. T. Averyt and H. L. Miller). Cambridge University Press, Cambridge, pp. 512-533.

Feller G. and Gerday C. (2003) Psychrophilic enzymes: hot topics in cold adaptation. Nat. Rev. Microbiol. 1, 200-208.

Feller G., Lonhienne T., Deroanne C., Libioulle C., Vanbeeumen J. and Gerday C. (1992) Purification, characterization, and nucleotide sequence of the thermolabile $\alpha$-amylase from the Antarctic psychrotroph Alteromonas haloplanctis A23. J. Biol. Chem. 267, 5217-5221.

Finke N. and Jørgensen B. B. (2008) Response of fermentation and sulfate reduction to experimental temperature changes in temperate and Arctic marine sediments. ISME J. 2, 815829.

Finke N., Vandieken V. and Jørgensen B. B. (2007) Acetate, lactate, propionate, and isobutyrate as electron donors for iron and sulfate reduction in Arctic marine sediments, Svalbard. FEMS Microbiol. Ecol. 59, 10-22.

Fukui M., Suh J., Yonezawa Y. and Urushigawa Y. (1997) Major substrates for microbial sulfate reduction in the sediments of Ise Bay. Jpn. Ecol. Res. 12, 201-209.

Glabe C. G., Harty P. K. and Rosen S. D. (1983) Preparation and properties of fluorescent polysaccharides. Anal. Biochem. 130, 287-294.

Hanssen-Bauer I. (2002) Temperature and precipitation in Svalbard 1912-2050: measurements and scenarios. Polar Rec. 35, 225-232.

Jakobsson M., Grantz A., Kristoffersen Y. and Macnab R. (2003) Physiographic provinces of the Arctic Ocean seafloor. Geol. Soc. Am. Bull. 115, 1443-1455.

Keil R. G. and Kirchman D. L. (1992) Bacterial hydrolysis of protein and methylated protein and its implications for studies of protein degradation in aquatic systems. Appl. Environ. Microbiol. 58, 1374-1375.

Keil R. G. and Kirchman D. L. (1994) Abiotic transformation of labile protein to refractory protein in sea-water. Mar. Chem. 45, 187-196.

Knoblauch C. and Jørgensen B. B. (1999) Effect of temperature on sulphate reduction, growth rate and growth yield in five psychrophilic sulphate-reducing bacteria from Arctic sediments. Environ. Microbiol. 1, 457-467.

Moritz R. E., Bitz C. M. and Steig E. J. (2002) Dynamics of recent climate change in the Arctic. Science 297, 1497-1502.

Loeng H., Brander K., Carmack E., Denisenko S., Drinkwater K., Hansen B., Kovacs K., Livingston P., McLaughlin F. and Sakshaug E. (2005) Marine systems. In Arctic Climate Impact Assessment - Scientific Report (eds. C. Symon, L. Arris and B. Heal). Cambridge University Press, Cambridge, pp. 453-538.

Myklestad S. M., Skanoy E. and Hestmann S. (1997) A sensitive and rapid method for analysis of dissolved mono- and polysaccharides in seawater. Mar. Chem. 56, 279-286.

Nagata T. and Kirchman D. L. (1996) Bacterial degradation of protein adsorbed to model submicron particles in seawater. Mar. Ecol. Prog. Ser. 132, 241-248.

Robador A., Brüchert V. and Jørgensen B. B. (2009) The impact of temperature change on the activity and community composition of sulfate-reducing bacteria in arctic versus temperate marine sediments. Environ. Microbiol. doi:10.1111/j.1462-2920. 2009.01896.x.

Sørensen J., Christensen D. and Jørgensen B. B. (1981) Volatile fatty-acids and hydrogen as substrates for sulfate-reducing bacteria in anaerobic marine sediment. Appl. Environ. Microbiol. 2, 5-11.

Stein R. and Macdonald R. W. (2004) Organic carbon budget: Arctic Ocean vs. global ocean. In Organic Carbon Cycle in the Arctic Ocean (eds. R. Stein and R. W. Macdonald). Springer, Berlin, pp. 315-322.

Weston N. B. and Joye S. B. (2005) Temperature-driven decoupling of key phases of organic matter degradation in marine sediments. PNAS 102, 17036-17040.

Widdel F. and Bak F. (1992) Gram-negative mesophilic sulfatereducing bacteria. In The Prokaryotes (eds. A. Balows, H. G. Trüper, M. Dworking, W. Harder and K.-H. Schleifer), second ed. Springer, New York, pp. 3352-3378.

Associate editor: Thomas S. Bianchi 